\title{
COVID 19 PANDEMIC: A PSYCHOLOGICAL AND SOCIAL IMPACT TO THE EFFECTIVENESS OF TEACHERS FROM THE SECONDARY TEACHERS OF VICTORIA LAGUNA
}

\author{
Sheryl O.Laraño \\ Faculty, Nanhaya National High School
}

Article DOI: $\underline{\text { https://doi.org/10.36713/epra7633 }}$

DOI No: 10.36713/epra7633

\begin{abstract}
The Purpose of this study is to determine the Psychological and Social Impact of Covid 19 pandemic to the Teachers Effectiveness from the Ninety Four ( 94 ) Secondary Teachers of Victoria,Laguna.

A questionnaire was proposed and was approved, this was administered thru google platform with the permission of the Secondary School Heads and Public District Supervisor through a formal letter to disseminate the questionnaire to the respective teacher respondents from the different Secondary Schools in Victoria, Laguna.The Questionnaire composed and based from the statement of the Problem (1) The Demographic profile of the respondents such as age,gender,status,position.(2) What are the Psychological Impact of Covid 19 pandemic to the secondary teachers in terms of anxiety,fear,stress (3) Social Impact of covid 19 pandemic to the Secondary Teachers of Victoria, Laguna in terms of responsiveness and commitment, (4) What are the impact of covid 19 pandemic to teachers effectiveness in terms of the teacher and the profession. (5)Is there a signifanct relationship between the psychological ans social impacts of covid 19 pandemic to teachers effectiveness.

Qualitative Research design was used to evaluate the Psychological and Social Impact of covid 19 pandemic to teachers effectiveness. The researcher submit a formal letter to Public School District Supervisor of Victoria to ask a permision to conduct a study to her scope and also ask permission to the School Head for disseminating the questionnaires for the teacher respondents.Google form was a platform used to answered the questionnaires it was answered by the (18) teachers from Banca Banca Integrated National High School, (13) teachers from Masapang Integrated National High School,(13) teachers from Nanhaya National High School (5) teachers from San Benito National High School (21) teachers from San Francisco Integrated National High School (15) teachers from San Roque National High School and (9) teachers from Victoria Senior High School total of (94) respondent.

Based on the findings of the study, the following conclusion were made, There is a significant relationship in the psychological and social impact of covid 19 Pandemic to the teachers effectiveness of secondary teachers of Victoria,Laguna. The Hypothesis stated that there is no significant differenence from the psychological and social impact to the teachers effectiveness.
\end{abstract}

\section{INTRODUCTION}

The Department of Education abbreviated as DepEd is the Executive Department of the Philippine Government responsible for ensuring access to, promoting equity in and improving the quality basic education. It is the main agency tasked to manage and govern Philippine system of basic education. It is a chief formulator of the Philippine Education Policy and responsible for the Philippine primary and secondary school system (Wiki 2020).

The Coronavirus Disease (COVID-19) is an infectious disease caused by newly discovered coronavirus. Most people infected with this will experience mild to moderate respiratory illness and recover without requiring special treatment. Older people and those with underlying medical problems like cardiovascular disease, diabetes, chronic 
respiratory disease and cancer are more likely to develop serious illness. It is spread primarily through droplets of saliva or discharge from the nose when an infected person cough or sneeze (WHO 2020).

Considering the increase of cases in the Philippines, the researcher decided to find out the possible impact of the outbreak to the people, particularly to the teachers on how they will deal with the quarantine period. The Department of Education would have ended the school year for the basic level institutions in late March 2020, the classes were shortened in the middle of the month in case of an extension of the suspension of face to face education on the school year 2020-2021 due to the pandemic (K.T et.al 2020).

The present pandemic has brought extra ordinary challenges and has affected the educational sectors, and no one knows when it will end. Every country is presently implementing plans and procedures on how to contain the virus and infections are still continually rising (J.Tria 2020).

The pandemic has led teachers to an unpredictable scenario where the lockdown situation has accelerated the shift from traditional to online educational methods and relationship have been altered by the avoidance on direct contact with others with implications for their mental health. Physical activity seemed to be a factor that could prevent mental disorders such as anxiety or depression in this peculiar situation.

Despite governments effort to provide training and resources to support Teachers in adapting to this new learning environment turning from face to face to virtual classroom in such a short time has been a challenge as only a few teachers have strong digital and ICT skills, therefore in such unprecedented and uncertain times, it is normal for teachers to experience higher level of stress and anxiety. Teachers need, indeed socio-emotional support to face extra pressure being put on them to deliver learning in time of crisis. (UNESCO 2020). Moreover, providing support for teachers own psychosocial well-being is an essential component of supporting students (IASC, 2007).

\section{STATEMENT OF THE PROBLEM}

This Research titled Covid 19 Pandemic: A Psychological and Social impact Teachers Effectiveness to the Secondary Teachers of Victoria Laguna District aims to determine the Impact of the Covid 19 pandemic to the Teachers effectiveness and specifically it seeks to answer the following questions:
1.What is the Demographic Profile of the Respondents in terms of:

$$
\begin{aligned}
& \text { 1.1 Age } \\
& \text { 1.2 Gender } \\
& \text { 1.3 Status } \\
& \text { 1.4 Position }
\end{aligned}
$$

2. What are the Psychological Impacts of covid 19 to the Secondary Teachers of Victoria District in terms of;

2.1 Anxiety

2.2 Fear

2.3 Stress

3.What are the Social Impact of Covid 19

Pandemic to the Secondary Teachers of Victoria

District in terms of;

3.1Repsonsiveness

3.2 Commitment

4. What are the impact of covid 19 pandemic to Teachers Effectiveness bought by the COVID-19

Pandemic as to:

4.1 The Teacher and the Profession

4.2 The Teacher and the Learners

4.3 The Teacher and the Parents

4.4 The Teacher and the State

4.5 The Teacher and the Community

5. Is there a Significant relationship between the Psychological and Social Impacts of covid 19 pandemic to Teachers Effectiveness?

\section{RELATED LITERATURE}

Since the end of 2019, a coronavirus type has started to threaten the human life in Wuhan (China). Due to the scale of the threat, it is labeled as a "pandemic" by World Health Organization (WHO) in 11th of March. It is the first pandemic announcement by WHO which is caused by a type of coronavirus and WHO warns all local authorities to raise their health emergencies to maximum level (WHO, 2020). An estimation by UNESCO shows that more than 1.5 billion of students and 63 million of educators are affected by school closures in 188 countries as the date of March 27, 2020 (UNESCO, 2020). Due to uncertainty on schedules, applications for most graduate programs are delayed to a particular time or canceled around the world (OECD, 2020). At the early stages of pandemic, it is perceived as a matter of public health, however, characteristics of fast contamination and stamina in diverse objects make COVID-19 a more critical issue (Burgess,Sievertsen, 2020).

The COVID-19 pandemic has affected education, and teacher education in particular, in various ways. As a result of the closure of universities and schools, 
teachers and students had to rapidly adapt to remote teaching. Teacher education is no exception. The need to create learning environments for student teachers doing their teacher education preparation implied decisions, choices and adaptations in order to meet not only the expectations of students but also the requirements of teacher education as well as the conditions in which both universities and schools had to operate (Flores and Gago 2020).

\section{FINDINGS}

The statistical data revealed the following

1. Teachers' Perceptions on the Psychological Impact of COVID-19 Pandemic with regard to Anxiety: Experienced trouble concentrating in work from home schedule due to unconducive workplace is low ( $\mathrm{M}=3.52$, SD, 1.133 ) Distressed on what happening in our surroundings together with loads of paper works is low ( $M=4.07, S D=0.930)$. Distressed on what happening in our surroundings together with loads of paper works is low ( $\mathrm{M}=3.55, \mathrm{SD}=1.142$ ). In terms of our nature of work one of the majors suffer is the inability to relax is low ( $M=3.97,0.955$ ) and Most of the teachers have burn out after giving and retrieving modules and activities is also low ( $\mathrm{M}=4.01, \mathrm{SD}=0.910$ ) the over all mean is 3.83 intepreted low.

2. Teachers' Perceptions on the Psychological Impact of COVID-19 Pandemic with regard to Fear: Frustration of teachers from covid 19 maxed out because of continue rising of cases is low ( $\mathrm{M}=4.15, \mathrm{SD}=0.892$ ). Feeling unsafe of going out frightened that we may encounter virus carrier was very low ( $\mathrm{M}=4.40, \mathrm{SD}=0.799)$. Afraid to get sick or worse die for personal reason like contagion from disease and leaving the family members was very low ( $\mathrm{M}=4.47, \mathrm{SD}=0.758$ ). I feel my life is threatened by the corona virus because it can hit anybody was very low $(\mathrm{M}=4.39, \mathrm{SD}=0.845)$ and Struggling of going back to face to face after hearing the new variant of covid 19 pandemic was very low also the over all mean is 4.36 interpreted as very low.

3. Teachers' Perceptions on the Psychological Impact of COVID-19 Pandemic with regard to Stress: Hard to lower the stress level until covid 19 pandemic ends is low ( $\mathrm{M}=3.99$, $\mathrm{SD} 0.836$ ). Change in behavior particularly as it relates to irritability and concentration is low ( $\mathrm{M}=3.55, \mathrm{SD}=1.215$ ). May not maintain productivity specially when other works are in the school is low $(\mathrm{M}=3.71, \mathrm{SD}=1.132)$. Workload from school brought to home to attain other school work is very low ( $\mathrm{M}=4.22, \mathrm{SD}=0.844)$. Distracted from work from home set up due to other family members movement ( $\mathrm{M}=3.69, \mathrm{SD}=1.173)$.The overall mean is 3.83 which interpreted as low.

4. Teachers' Perceptions on the Social Impact of COVID-19 Pandemic in terms of Responsiveness: Difficulties to know more about students because we are not practicing face to face since the pandemic started is very low ( $M=4.47, \mathrm{SD}=0.651)$. Cannot practice community services due to protocols implemented by IATF is very low ( $\mathrm{M}=4.39, \mathrm{SD}=0.643$ ). Unable to practice school organization and projects because there are no students' involvement is very low ( $\mathrm{M}=4.43, \mathrm{SD}=0.647$ ). Difficulties to get acquainted with the parents specially from the parents of new students is very low ( $\mathrm{M}=4.37, \mathrm{SD}=0.672$ ). Hard to find stakeholders in pandemic time most of the stakeholders are tight due to pandemic ( $\mathrm{M}=4.37, \mathrm{SD}=0.672$ ) the over all mean is 4.41 which interpreted as very low.

5. Teachers' Perceptions on the Social Impact of COVID-19 Pandemic in terms of Commitment: Cannot fully do the task assigned due to work arrangement schedule was not 100 percent attending in school is low ( $\mathrm{M}=4.18, \mathrm{SD}=0.789)$. Cannot practice face to face due to covid 19 pandemic which teachers and students sacrifice in learning is very low ( $\mathrm{M}=4.37, \mathrm{SD}=0.672$ ). Hard to facilitate learning for modular activities most specially when encountering uncooperative parents is very low ( $\mathrm{M}=4.21 . \mathrm{SD}=0.746$ ). Extended time for those students who help their parents in daily work to support their families is very high ( $\mathrm{M}=4.33, \mathrm{SD}=0.709)$. Difficulties encountered in work from home schedule like lack of materials need for printing of activities and modules is very low ( $M=4.21,0.717$ ) over all mean is 4.26 which is interpreted as very low

6. Teachers' Perceptions on their Teaching Effectiveness with the Teacher and the Profession Aspect: I am not confident if my students are the one answering the modules or the family member is very low ( $\mathrm{M}=4.20, \mathrm{SD}=0.742$ ). My teaching strategy may not be adequate due to the new flatform initiated by Deped is low ( $\mathrm{M}=3.96, \mathrm{SD}=0.789)$. Teachers Performance Rating may be greatly affected due to covid 19 pandemic is low ( $\mathrm{M}=4.02, \mathrm{SD}=0.733)$. I find difficulties in my strategies since some of my students do not have gadgets and internet connections is very low ( $\mathrm{M}=4.32, \mathrm{SD}=0.722$ ) and, I sacrifice may safety for the distribution of modules and home visitation for those who cannot reach for their modules is very high ( $\mathrm{M}=4.45, \mathrm{SD}=0.728$ ) over mean is 4.19 which interpreted as low.

7. Teachers' Perceptions on their Teaching Effectiveness with the Teacher and the Learners 
Aspect: I feel stress if my students fully understand the topic since there is no face-to-face learning is low ( $\mathrm{M}=4.14, \mathrm{SD}=0.742$ ). Some of the actual output of the students based from their modules were not their work is low ( $\mathrm{M}=4.11, \mathrm{SD}=0.725$ ). I am extending beyond class hours for the needs and concerns of my students is very high ( $\mathrm{M}=4.38, \mathrm{SD}=0.658)$. Follow up on the students output to further enhance modular instruction is very high ( $\mathrm{M}=4.38, \mathrm{SD}=0.607$ ) and Distressed about flood messages from the students queries since we are not practicing face to face is low ( $\mathrm{M}=3.97, \mathrm{SD}=0.796$ ) overall mean is 4.20 which interpreted as very low

8. Teachers' Perceptions on their Teaching Effectiveness with the Teacher and the Parents Aspect: Absence of Parental Guidance is low ( $\mathrm{M}=3.97, \mathrm{SD}=0.740$ ). Uncooperative Parents is low ( $\mathrm{M}=3.94, \mathrm{SD}=0.745)$ Too much expectations of parents to the grade of their children is low ( $\mathrm{M}=3.95, \mathrm{SD}=0.739$ ). Parental Stress complains is low ( $\mathrm{M}=4.00, \mathrm{SD}=0.775$ ) Deficiencies and seeking parents' cooperation in group conversation and home visitation ( $\mathrm{M}=3.96, \mathrm{SD}=0.775$ ) overall mean is 3.96 which interpreted as low.

9. Teachers' Perceptions on their Teaching Effectiveness with the Teacher and the State Aspect: Government/LGU providing safety precautions to the teachers for their job amidst pandemic is high ( $\mathrm{M}=$ 4.07, $\mathrm{SD}=0.692$ ). Teachers cannot actualize the full commitment of their devotion due to restrictions of covid 19 pandemic is low $(\mathrm{m}=4.12, \mathrm{SD}=0.716)$. Lack of teamwork among teachers due to arranged work schedule is low ( $\mathrm{M}=4.03, \mathrm{SD}=0.740)$. Inadequate stakeholders' involvement to school is low ( $\mathrm{M}=3.93, \mathrm{SD}=0.692$ ) and Difficulties on Physical meetings with students ( $\mathrm{M}=4.27, \mathrm{SD}=0.706$ ) over all mean is 4.08 which is interpreted as low.

10. Teachers' Perceptions on their Teaching Effectiveness with the Teacher and the Community Aspect: Struggling to conduct and participate in community involvement and community services is very low ( $\mathrm{M}=4.23, \mathrm{SD}=0.710$ ). Inability to provide online lesson due to lack of gadgets is very low ( $\mathrm{M}=4.29, \mathrm{SD}=0.742$ ). Cannot practice to render the best service that I can provide to stakeholders and community due to hassle impact of pandemic is very low ( $\mathrm{M}=4.20, \mathrm{SD}=0.679$ ). Some stakeholders in the community thinks teacher were give lesser work is very low $(M=4.39, S D=0.691)$. Most of the announcement and communication done through online ( $\mathrm{M}=4.53, \mathrm{SD}=0.581)$ overall mean is 4.33 which interpreted as very low

11. Relationship between the Psychological Impact of the COVID-19 Pandemic and Teaching Effectiveness.
The Teacher and the profession as to Anxiety $r=0.456, p=0.000$, analysis is $S$, as to Fear $r=0.559, p=0.000$, Analysis is $S$, as to stress $\mathrm{r}=0.564, \mathrm{p}=0.000$,Analysis is $\mathrm{S}$. The teacher and the learner as to Anxiety $\mathrm{r}=0.562, \mathrm{p}=0.000$ Analysis is S.Learner as to Fear $\mathrm{r}=0.515, \mathrm{p}=0.000$ analysis is S.Learner as to Stress $r=0.622 \mathrm{p}=0.000$ analysis is $\mathrm{S}$. The learner as to parent $\mathrm{r}=0.419, \mathrm{p}=0.000$ Analysis is $\mathrm{S}$. as to Fear $\mathrm{r}=0.322, \mathrm{p}=0.001$, Analysis is $\mathrm{S}$. As to stress $r=0.409$ Analysis is S.The teacher and the state as to anxiety $\mathrm{r}=0.317, \mathrm{p}=0.002$, analysis is $\mathrm{S}$. As to Fear $r=3.58, p=0.000$, analysis is $\mathrm{S}$.As to Stress $\mathrm{r}=$ $0.049, \mathrm{p}=0.000$, analysis is $\mathrm{S}$.The teacher and the community as to anxiety $\mathrm{r}=0.308, \mathrm{p}=0.003$, analysis is $\mathrm{S}$. As to Fear $\mathrm{r}=0.376, \mathrm{p}=0.000$, analysis is $\mathrm{S}$.As to stress $\mathrm{r}=0.413, \mathrm{p}=0.000$, analysis is $\mathrm{S}$.

12. Relationship between the Social Impact of the COVID-19 Pandemic and Teaching Effectiveness: The Teacher and the profession as to responsiveness $\mathrm{r}=0.623, \mathrm{p}=0.003$, Analysis is $\mathrm{S}$. As to commitment $\mathrm{r}=$ $0.602, \mathrm{p}=0.000$,Analysis is $\mathrm{S}$. The Teacher and the Learner as to responsiveness $r=0.598, p=0.003$, analysis is $\mathrm{S}$. As to commitment $r=0.616, p=0.000$, analysis is S.The teacher and the parents as to responsiveness $r=$ $0.474, \mathrm{p}=0.003$, analysis is S.As to commitment $\mathrm{r}=0.433, \mathrm{p}=0.003$, analysis is $\mathrm{S}$. As to commitment $\mathrm{r}=0.433, \mathrm{p}=0.000$, analysis is $\mathrm{S}$. The teacher and the state as to responsiveness $\mathrm{r}=0.449, \mathrm{p}=0.003$, analysis is S.As to Commitment $\mathrm{r}=0.436, \mathrm{p}=0.000$ analysis is S.The teacher and the community as to responsiveness $\mathrm{r}=0.600, \mathrm{p}=0.003$, analysis is $\mathrm{S}$.

\section{CONCLUSION}

Based on the findings of the study, the following conclusion were made.There is a significant relationship in the psychological and social Impact of Covid 19 Pandemic to the teachers effectiveness of secondary teachers of Victoria, Laguna. The hypothesis stated that there is no significant difference from the psychological and social impact to the Teachers Effectiveness

\section{RECOMMENDATIONS}

Based on the findings and conclusions of the study, the following are recommended

1. The District Office of Vctoria,Laguna may include in the Basic Education Continuity Plan due to this pandemic, The Psychological and social well being through webinars for the teachers to further deepen the awareness of teachers the circumstances brought by the pandemic 
2. It is Important for the Teachers to Facilitate and practice Physical activity at home specially that they are practicing the work from home schedule to prevent health and mental problems among teachers in future similar situation

3. Teachers are adapting the New Normal it is very essential for the teachers to stay in considerable hard work for the challenges in education made by the covid 19 pandemic, to still be more committed with their professional oaths and stay in focus for the benefits of the learner and for continuous shaping the knowledge for the learner

4. The Teachers are the backbone of the society, amidst the pandemic the teachers should continouosly contribute and participate with regards of the projects of the LGU's to eliminate state's problem, desiminating in formation from the IATF protocols may be a great contribution by the teachers.

\section{REFERENCES}

1. A.Vatne Bintliff Ph.D (2020) How Covid 19 has influenced Teachers

2. Burgess and Silversten (2020) School,Skills and learnining:The impact of covid 19 to education

3. C.Cipriano,Marck Bracket ( 2020 ) :Social Emotional Learning:Teacher are anxious and overwhelmed,They need SEL more than ever

4. C.Ebape BR (2021) Vol.18 Rio de Janeiro

5. Collie and Martin (2018) Teacher and student replationship

6. C.Masach (2016) Understanding the Burnout experiences

7. D.Schaffhauser (2020) The emotional impact of covid 19:Research Students Feeling stressed so are their teacher

8. Flores and Marilia Gago ( 2020 ) Teacher Education in times of pandemic

9. F.Reimers (2020) Supporting the continuation of teaching and learning during the covid 19 pandemic

10. K.Jian (2020) How do Nacebo Phenomena provide a theoretical framework for the covid 19pandemic

11. Gao et al (2020) Mental Health Problems and Social media exposure for the covid 19 pandemic

12. Gago Ma. (2020) Teacher Education in times of Covid 19 Pandemic in Portugal:National Institutional and Pedagogical responses

13. IASC (2020) Covid 19 Outbreak Readiness and Responses:World Health Organiztion
14. J.Moreno and L.Gortazar (2018) Schools readiness for digital learing in the eyes of principals.An Analysis from PISA 2018 and its implication to covid 19 crisis response

15. J.Tria (2020) The covid 19 pandemic through the lens of education in the Philippines:The New Normal

16. K.T et al ( 2020 ) Covid 19: In search of silver linings

17. L. Apperibai ( 2020 ) Manila Bulletin

18. Mc.Clinton ( 2015 ) Mental health tips for teachers in New York,Manual for Teachers,Psychologist and Guidance counselors

19. Philippine star (2020) Interaksyon

20. P.and Ch Steachteas ( 2020) The psychological impact of the covid 19 pandemic on secondary schools teachers

21. R.Abaci (1995) Coping with Teachers Stress

22. Reynolds (2020) The psychological impact of covid 19 on the mental health in the general population

23. RJ Collie (2020) Covid 19 and the Teachers somatic burden,stress and emotional exhaustion examining the role of the principal leadership and workplace bouyancy

24. R.Collins (2020) Social Distancing as a critical test of microsociology of solidarity

25. R Youngs ( 2020 ) Civil Society and the Corona Virus:Dynamism Despite Disruption

26. S.Rahid et al ( 2020 ) implementing social distancing policy measure in the battle against the corona virus

27. Sahu (2020) Closure of universities due to Corona Virus Desease

28. S. Guerero ( 2020 ) GPE Tranforming Education:teacher Leadership in times of Covid 19 Pandemic

29. T.Gonzales (2020) Influence of Covid 19 confinement on students

30. The Head Foundation (2020) The Philippine Covid 19 and its impact on higher education in the Philippines

31. World Health Organization ( 2020 ) Corona Virus Disease Situation Report

32. UNESCO BANGKOK (2020) Situation Analysis and effects of an responses to covid 19 in the education sector in Asia "UNESCO BANGKOK Asia Pacific Beauru for Education

33. UNESCO (2020)How Teachers ARE Leading Efforts to ensure Learnings Never Stop During the Covid 19 Education Disruption

34. Varkey Foundation ( 2020 ) Parent Teacher Partner The need to reviewed collaboration in the time of covid 19 